\title{
LANGUAGES OF TRAUMA
}

History, Memory, and Media 
This page intentionally left blank 


\section{Languages of Trauma}

History, Memory, and Media

EDITED BY PETER LEESE, JULIA BARBARA KÖHNE, AND JASON CROUTHAMEL

UNIVERSITY OF TORONTO PRESS

Toronto Buffalo London 
(C) University of Toronto Press 2021

Toronto Buffalo London

utorontopress.com

Printed in the U.S.A.

ISBN 978-1-4875-0896-8 (cloth) ISBN 978-1-4875-3941-2 (EPUB)

ISBN 978-1-4875-3940-5 (PDF)

\section{Library and Archives Canada Cataloguing in Publication}

Title: Languages of trauma : history, memory, and media / edited by Peter

Leese, Julia Barbara Köhne, and Jason Crouthamel.

Names: Leese, Peter, editor. | Köhne, Julia, editor. | Crouthamel, Jason, editor.

Description: Includes index.

Identifiers: Canadiana (print) 2020041612X | Canadiana (ebook) 20210091924 |

ISBN 9781487508968 (hardcover) | ISBN 9781487539412 (EPUB) |

ISBN 9781487539405 (PDF)

Subjects: LCSH: Psychic trauma in literature. | LCSH: Psychic trauma in the theatre. | LCSH: Psychic trauma in motion pictures. | LCSH: Psychic trauma in music. | LCSH: Psychic trauma and mass media. | LCSH: Memory in art. | LCSH: Memory in literature. | LCSH: Memory in motion pictures. |

LCSH: War films - History and criticism. | LCSH: War in literature.

Classification: LCC NX650.M46 L36 2021 | DDC 700/.453 - dc23

University of Toronto Press acknowledges the financial assistance to its publishing program of the Canada Council for the Arts and the Ontario Arts Council, an agency of the Government of Ontario.



Canada Council for the Arts

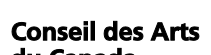

du Canada

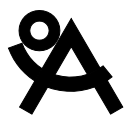

ONTARIO ARTS COUNCIL CONSEIL DES ARTS DE L'ONTARIO

an Ontario government agency

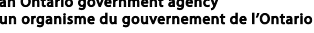

Funded by the Financé par le Government gouvernement of Canada du Canada 
Dedicated to our inspiring colleague Thomas Elsaesser 
This page intentionally left blank 